\title{
Topography of power relations in Slovak preschool sector based on Bourdieu's field theory ${ }^{1}$
}

\section{Ondrej Kaščák, Branislav Pupala}

\begin{abstract}
The article analyses the Slovak preschool education sector using Bourdieu's field theory. It describes stable and volatile points in the evolution of preschool education in terms of the power games occurring within the specific social field of power relations shaped during these games. It explores the groups of powerful players that represent the political, civic-professional and academic sub-fields exerting an influence over the preschool field who in different ways and at various times control the preschool field and structure within it the hierarchy of power relations in preschool education governance. The analysis is empirically illustrated; the power relations played out and were renewed when the national preschool curriculum was undergoing fundamental change. It describes the strategies, processes and consequences of changes in the power relations between the sub-fields and the associated behaviour of the actors. The analysis shows how the power conflicts ultimately led to the homologous relations between the sub-fields transforming into democratically-structured power relations in preschool education governance.
\end{abstract}

Key words: field theory, social field, specific field, sub-field, Bourdieu, Slovakia, curriculum, preschool education.

\section{Introduction}

The preschool education sector has been undergoing dynamic change and hence there is a need to explain the causes of these changes and ascertain

This work was supported by the research projects VEGA 1/0057/15, VEGA 2/0140/15, KEGA 005TTU-4/2015, KEGA 006TTU-4/2017. 
their impact on the sector. A number of theoretical approaches can be used to describe these changes, depending on the aspect of the education sector we wish to focus on. In this article we look at education policy, the groups of actors involved in preschool decision-making and the power relations between existing groups of actors. We do this from a social theory perspective and so P. Bourdieu's theory of social fields is a logical choice (Lima \& Campos, 2015).

Bourdieu defines a social field as "a multi-dimensional space of positions" (1985, p. 724). The form a social field takes "defines the state of the power relations, institutionalized in long-lasting social statuses, socially recognized or legally guaranteed, between social agents objectively defined by their position in these relations" (p. 725). Bourdieu's concept is therefore appropriate for analysing social sectors in which there are strongly institutionalised relations and ties between the social groups who engage in that sector and seek to participate in decision-making processes.

The education sector, or in Bourdieu's phraseology the education field, is well-suited to this type of analysis. Several analyses have been conducted within this field; nonetheless, the preschool education sector has not been described in sufficient empirical depth from a field theory perspective. A number of studies exist on conceptual and methodological issues relating to Bourdieu's field theory and its use in explorations of the education sector (Grenfell \& James, 2004; Grenfell, 2009; Ferrare \& Apple, 2015) and research has also been performed analysing the "school field" in a local setting (André \& Hilgers, 2015), the higher education field (Naidoo, 2004), the field of post-secondary education in Alberta (Schmaus \& Wimmer, 2013) and the policy field of education in relation to PISA testing (Mangez \& Hilgers, 2012).

\section{Field Theory and Preschool Education}

Bourdieu (1985, p. 724) describes a field as a structured social space, "as a field of forces, i.e., as a set of objective power relations that impose themselves on all who enter the field and that are irreducible to the intentions of the individual agents or even to the direct interactions among the agents". Although here one might gain the impression that power relations are immutable, as conceived of in social field theory they display "relative autonomy" (Mangez \& Hilgers, 2012, p. 191). Each social field, including the education field, is subordinated to what Bourdieu calls the "field of power" (Bourdieu, 1993), which corresponds to the general power constellations at nation-state level (Buchholz, 2016). The "field of power" (as a "meta-field" - 
Schmaus \& Wimmer, 2013, p. 99) shapes the power relations at both the social-field level (for instance, the education field) and in "specific fields" (Hilgers \& Mangez, 2015, p. 8); here, the field of preschool education.

In addition to external factors, internal factors within certain "sub-fields", mainly the potential to influence different opinion platforms or groups in that field, also affect the way fields operate (Bourdieu, 1985). Where the specific field of preschool education is concerned, there are many such "subfields" - formal and less formal nursery school teacher groups, professional associations, unions, groups of employees responsible for preschool education at the education ministry, expert commissions for preschool education in government organisations, and so forth. These "sub-fields" engage in processes of value negotiation, mutual interaction and influence one another. In this way a particular image emerges of the power relations within the specific field of preschool education.

There is one more limiting factor. The "field of power" that for Bourdieu was bound to the specific conditions of the nation state is not a fully autonomous field in the present era. As Buchholz (2016) rightly states, to reflect current conditions field theory has to be extended to include a global or transnational field that exerts an influence on the constellation and relations between the various social fields within the nation state. Ratwolle and Lingard (2008) demonstrate how global institutions such as the OECD, UN or World Bank create new global fields of power that bring about changes in the arrangement and constellation of social fields at nation-state level, prompting the restructuralisation of social fields within the nation state. In connection to the theory of social fields, Mangez and Hilgers (2012) show for instance the effect OECD PISA testing has on the social field. One can expect a similar effect to be exerted on the specific field of preschool education by for example the OECD's ongoing global strategy for testing preschool-age children (the International Early Learning and Child Well-being Study - IELS).

\section{Method of Analysis and Field History}

As Hilgers and Mangez (2015) rightly state, field theory is essentially a means of analysing relations. It posits three basic aims - to determine the position and degree of autonomy of the field within the social arena; to describe and understand its specific rules and symbolic order (declarative activities, polemics, battles etc.); to identify the main individual and collective actors. We will consider each of these three basic aspects of field theory in our analysis of the specific field of preschool education in the Slovak Republic. 
We shall begin with our first step, which is to describe the evolution of the field's position within the Slovak social arena and its degree of autonomy.

From the 1950s onwards, the social field of Slovak education was not an autonomous field. It was strictly controlled by the "field of power" - the communist regime. This latter was responsible for the specific field of preschool education being established early on; however, it was homogenous in structure and had a minimal number of actors or sub-fields. It was not until after the fall of communism in 1989 that additional sub-fields were created and power relations were redistributed within the specific field.

The fact that preschool education has a strong tradition in former communist countries and that it received substantial backing from the outset means firstly that it easily became embedded as a legitimate part of the wider education field and secondly that it was able to shape itself as a specific field.

The late 1940s can be identified as the era in which this specific field began to be shaped. It then underwent a long, relatively stable and peaceful existence under the communist regime until the fall of communism brought with it a period of dynamism and internal differentiation. The last five years or so have been more turbulent, with the transforming (from the social and cultural field to the economic field of power) global field of power entering the arena, and the preschool education sub-field undergoing a marked differentiation associated with the entry of new actors into the specific field and the subsequent emergence of new power relations, tensions and the re-arrangement of these relations.

If we return to the long period in which the preschool specific field enjoyed a relatively peaceful existence in the communist 1940s and look at the nature of the power structures established under the communist regime and how they operated, we can see that this field and the relations within it displayed a simple, rigid, schematic and hierarchically fixed arrangement. During this period its boundary and structure were circumscribed by the monolithic political education field, within which the preschool specific field had its own defined space and position as part of maintaining the power goals and relations of the political education field as a whole. The players or actors within this preschool specific field were an effective tool for achieving the overall political goals and did not create additional sub-fields in which they might pursue specific goals and different interests. The actors in the preschool specific field operated within a monolithic homologous structure. 
On the other hand the specific nature of preschool education, its relative independence within the institutional education field, the professional saturation and the fact that it was rooted in the point at which the social, cultural, and education fields met gave it a certain symbolic and de facto degree of special standing as an institution, despite it belonging to the political education field of communist society. This meant that even under communism the preschool field can be regarded as a relatively independent special field with its own fixed hierarchy and the homologous structure and set-up referred to above. Hierarchically it contained only two groups of actors: those at the top, legitimising state power within the preschool sector (in terms of having responsibility for the preschool curriculum and for methodologies, nursery school inspections and teacher training); and a homogenous group of preschool educators - teachers operating as a single unit with a uniform professional identity and clearly subjugated to political power.

Within the narrow restraints of this hierarchy, the specific preschool field operated as an extremely disciplined entity with a simple structure, having formed its own collective identity as a hierarchically arranged preschool profession whose mission was early years education. The hierarchical rigidity, discipline and stable composition of this power structure was understandable given the absence of any diversifying power-sharing elements, for example professional associations or other preschool education interest groups. This homologous and fixed structure of a politically controlled specific field constitutes the basis on which each specific field operates, and the preschool field of the communist era is no exception.

With the fall of the regime in 1989 one might have expected to see sudden changes in the power relations in this field and a dramatic redistribution of the power hierarchies. While former communist countries did undergo rapid power reorganisations in other areas, particularly the economic and political sectors, this was not the case with the education sector (owing to its nature and the generally shared belief in Slovakia that it had not hitherto proved possible to fundamentally reform the sector). The homologous and rigid power hierarchy of the preschool field shaped under communism survived into the postcommunist era relatively untouched. The only change observable during this period was the minor formal democratisation of power relations in the preschool field, visible in for instance the newly created professional preschool teacher organisations. Two such organisations were created: the Society of Preschool Education (SVP) and the Slovak branch of OMEP, the World Organisation for Early Childhood Education (both formed in 1993). The structural diversification of preschool education began with 
the emergence of a private sector, represented by the independent Association of Private Schools and School Facilities (ASŠ).

However, these professional associations presented no threat to the existing power structure in the preschool field. They may have formally emerged on the platform of an emerging democratic civil society as joint players (or opponents) in the public sphere; however, in the case of the preschool field they were simply a means of expressing professional cohesion among the main preschool education actors, largely nursery school teachers for understandable reasons. In fact it was through these associations that the hegemony of the preschool specific field should have been declared and strengthened because they contained actors from all levels of the hierarchy, including political ones. One should also point out that there were no policy distinctions between two of these professional civic organisations (SPV and OMEP) and that there was considerable membership overlap.

Given this and the continued homologous power constellation in preschool education, during the first two decades of democracy preschool education underwent gradual shifts and inconspicuous changes without experiencing power conflicts or tensions. The overall political and social changes led to a reduction in the availability of preschool education (the number of nursery schools fell and crèches disappeared), but this perceived threat merely served to bring actors in the preschool education field closer together.

In addition innovations and changes to the national preschool curriculum were introduced without provoking difficulty or resistance. The initial changes were cosmetic (amendments to the national curriculum to remove communist declarations), then (in 2008) the entire education sector experienced large-scale curriculum change in addition to structural changes. However, again these changes were implemented without disturbing the hegemony of the traditional hierarchy and subordination of the actors in the preschool field. It was almost as if it was still not seen as important to differentiate the sub-fields and their power coordinates, and the homology - the operating principle - of the specific field retained its stability and was preserved. Inside, however, it was possible to see the main players for whom maintaining the hierarchy remained advantageous and beneficial in terms of power. By dominating the entire sector the political actors, representing the education ministry, the central body responsible for nursery school teaching materials and the nursery school inspection authorities were able to stabilise their position. 
The political actors used the homologous habitus of the preschool professional community that had shaped over time to become powerful leaders of the whole community, and adopting the strategy of actively engaging in the civic-professional sub-field, they obtained a natural position of dominance over the mass base of nursery school teachers. Although a sub-field was created under the new social conditions - comprising publishers of preschool materials - under these conditions their action radius (and therefore business) could only be legitimised by forming powerful connections with the civic-professional field, which in this case, however, also meant with the political field. This is illustrated in the fact that the manager of a private preschool education publishing concern is the chair of the largest professional association (the Preschool Education Society) and that political actors now compile or review publications. Their links with political actors via official (ministry) decisions on the appropriacy of publications for preschool education lend the publications legitimacy, and all this ultimately enables them, through the homologous behaviour of all the actors, to spread throughout the entire preschool field and satisfy the demand created and ultimately the interests of a business sub-field.

Finally, the subjective economic interests of many of the actors active in the sub-fields contributes substantially to the entire specific preschool field retaining its rigid and homologous mentality, because it underpins the financial flows that appeared in the preschool education field as a new element in its postcommunist guise. The powerful position of the publishing business sub-field does not, however, play an important role in the shifts associated with the conceptual basis of preschool education. This sub-field generally relies on an adaptive strategy and powerful links, which it seeks out, forms and changes to suit its commercial goals. However, this provides motivation to political actors who, interested in their profits, attempt to maintain a powerful influence on the preschool field as a whole.

\section{Changing Fields, Changing Relations}

The relative stability or rather rigidity of the preschool education field sustained throughout the first two decades of postcommunist Slovakia can also be seen as the reason for the long-term stability of conceptions of preschool education in Slovakia. In addition preschool education having special status under communism, aided by its ideological goals, it had long been associated with the social mission of the early socialisation of children and preparing them for a successful start to compulsory schooling. This is reflected in the fact that the field of power in education has largely been focused on the 
cultural and social objectives of education. So, just as one can observe a reversal in the lifelong learning sector and differences in the way first and second generation lifelong learning is defined (Rubenson, 2008), culture goals have now radically shifted to become economic ones. This neoliberal turn to the economic is also affecting preschool education as can be seen in the OECD and EU strategies which emphasise new roles for preschool education (a shift towards economic ones).

The structure of the global field of power is changing, establishing a new kind of educational order (Field, 2006), and this new order is also starting to appear in the preschool world. It is gradually invigorating and breathing life into the power fields, producing new actors, awakening new tensions and conflicts, and altering the quality and structure of power relations (Tesar et al., 2017). The preschool field is losing its specificity, becoming part of the discourses of the education field generally and starting to be more substantially reflected in the academic sphere, multiplying the number of political actors who are incorporating preschool education into their agendas. It is here that original homology of the established preschool community is being destroyed and reconstructed and explicit power games are appearing.

The first signal of a change in the power relations in Slovakia's preschool education field was emitted against the backdrop of the attempt to reform the education sector as a whole, when, in light of the shift in the global field of power towards economic goals in education, some curricular frameworks began to change (for example the introduction of standards into education programmes, the decentralisation of curriculum writing, the integration of school and preschool curricula). In 2008 for instance the preschool curriculum in Slovakia underwent radical change, but its creation and rapid adoption did not cause any serious upset, since they were in keeping with the prevailing homologous mentality of the actors. Indeed this homologous culture was unaware the domestic changes were occurring against the backdrop of the neoliberal changes to the global field of power.

However, the changes to the global field did activate new actors in the domestic specific preschool field. With more marked shifts occurring within global and national education, the academic actors made a strong entrance, establishing themselves as active players. They did not simply initiate and diversify the debate on preschool education, but they also entered the political sub-field and began actively to participate in preschool decision-making. This new group of actors, outside the original homologous structures of the preschool specific field, were forcing the original actors in what had been 
an internally undifferentiated field to clarify their power interests and hierarchical links and to articulate their opinions and aims. It has become far more possible to identify the criss-crossing layers of power connections between actors from the political, academic and civic-professional sub-fields. The preschool education dynamics extend into the strategic power relations between the actors, which are evenly based on strategic games, negotiations, on influencing various powerful figures, the mutual connections or shared interests with the opposition or coalition and partnerships of actors representing powerful groups.

Notwithstanding some historical moments, one can say that the academic sphere had its own actors in the specific field of preschool education. It is true to the extent that academics affiliated to preschool education were a visible part of this field. However, when the homologous power structure was in place they did not form an active powerful sub-field that could engage in the action. They engaged symbolically in the activities of professional associations and hence in the civic-professional field, functioning as a kind of intellectual ornament legitimising the status quo. In some cases they were behind the creation of certain education policy documents (for example the 2008 national education programme) and yet they no longer asserted nor sought power over its application and the outcomes. This simply passed into the hands and control of political actors. Hence the academic actors traditionally occupied a passive position in the preschool specific field.

The moment at which the academic sphere entered the preschool sector as an active player and relevant sub-field can be traced back to when, firstly as part of the transformation of the education sub-field as a whole, the status of preschool education within the education field once again became an important theme both academically and in terms of knowledge, and secondly when the issue of preschool education curricula began to be perceived as the subject of serious research on overlapping political, scientific and social interests. An academic group formed in Slovakia with this specific interest in mind established itself as an important academic sub-field and, based on its academic interests, spread out across the political, academic and education sectors, joining the power structure of the preschool specific sub-field. In doing so it disrupted the stable homologous hierarchy of power relations and the preschool sector was moulded into a field that would structurally diversify and see its power relations energised.

There are three basic sub-fields that play an active role in these relations and interconnections: the political, academic and civic-professional sub- 
fields. As our subsequent analysis on the power clashes between these subfields shows, it is not institutional affiliation (which can vary and is dynamic) that defines them so much as the instruments that they use or identify with. For the academic field the key instrument of power is knowledge. For the political sub-field it is the formally delegation of positions among actors in the system. While the civic-professional players draw on their emotional ties to the profession and tradition.

Although hypothetically the two sub-fields could work together, in Slovakia the powerful groups that emerge out of the actions of these sub-fields tend to be conflictual. This is because the hierarchy of power relations throughout the preschool field is changing and this requires things like leadership sharing and a weakening of the inert links between the traditional groups that dominant and are dominated. However, this is not easily achieved, given the powerful nature of the processes, and leads to various strategies being developed to maintain and assert power.

There are three differentiated sub-fields operating alongside one another, but they are not restricted to their institutional walls. Their powerful influences and various types of interconnections are energised by the fact that the originally isolated and powerless academic sphere is gaining political legitimacy by directly engaging in the changes affecting preschool education. One consequence of this differentiation is that amidst the changing traditional ties between the dominant and the dominated in the civic-professional field, hidden in the political field as well, there is a kind of ongoing emancipation that is producing new group of civic-professional players. They are setting up new professional associations, cleansed of any political infiltration, and these are becoming the new units in which power is distributed within the preschool specific field. The preschool section of the Slovak Chamber of Teachers (SKU) emerged in this way. It is a new autonomous actor in the civic-professional sub-field of preschool education and it is substantially changing its field of power. Quite consciously and in order to further differentiate and distribute power in the preschool field, another civic-professional group has appeared: the Slovak Association of Childhood Education International (SACEI). This group formed an alliance with the academic field so as to balance out the powerful ties between the political, civic-professional and academic sub-fields.

\section{Battle over the Curriculum}

The watershed moment that prompted the shift in power in the preschool 
specific field in Slovakia occurred when the academic sub-field that was gradually establishing itself gained legitimacy on the basis of its widely disseminated knowledge on issues concerning the creation of the new national preschool curriculum (in 2012). The actions of the academic sub-field led to a juncture being created between it and the political sub-field, opening up a competitive political leadership arena. Thus in fulfilling its political task the academic sub-field inevitably weakened the existing power structures which had grown up around the national curriculum that was being replaced with a new one.

Curricular innovation in preschool education was nothing new; since 1989 alone it had been undertaken at least three times, and in 2008 had led to the creation of a national curriculum that was structurally quite different to the ones the national preschool field had long been accustomed to. However, all the previous curricular innovations had been undertaken from within the closed homologous power structure of the preschool field with its stable power hierarchy and repeated reaffirmation. Up until 2008 each innovation had been presented as a natural element in the progression of preschool education, and was prepared directly at central government level and implemented without teacher involvement.

It was only when work began on the new national curriculum in 2012 that a new strategy for developing and introducing curricular innovation was called for. The political actors who had been involved in all previous innovations were replaced with actors from the academic field, and they had to confront the fact their position was being undermined by the new distribution of power. Their need to maintain their own positions of power generated mechanisms to defend against loss of power and to unseat the new players. A new strategy was therefore conceived - endless consultations on the new curriculum, designed to either ensure it was controlled by the original political actors or rejected outright. This strategy of having endless rounds of consultation (and author redrafts) was artificially propped up by the authors of the curriculum, who, representing the academic field and out of their desire to work alongside those in the civic-professional field, were themselves initiating consultations and discussions with representatives of the preschool teaching profession.

This strategy, which was continually pursued and renewed by the actors in the original academic field, is rarely adopted in curricular politics in Slovakia and had never previously been used to this extent nor in relation to innovation in other education programmes. It was manifestly clear that 
this was a power struggle and an attempt by the original political actors to prevent the new distribution of power. The fact that this process relied on power games also indicates the effect the long years of power homology had had on the preschool field and that it was completely unprepared for the sharing and democratic distribution of power.

Another unusual aspect is that the power struggle continued for four years and affected all the four ministries involved in the governance of the education sector. The instability of the education ministry, where ministers were replaced every year, became a key tool in the political sub-field's struggle for power. The proximity of the political sub-field to the minister's office enabled it to cast doubt on all the opinions of previous ministers and these were continually being redeployed in the battle between the political actors as novices. They were often taken aback that the innovate education programme had become such a strong power arena in preschool education. One former education minister, Juraj Draxler, stated in an article published in a serious newspaper (2017) recalled his time in ministerial office when the battle was at its most intense:

People were either not communicating or they were fighting. For example when the state nursery school education programme was being drafted two completely irreconcilable camps formed around the issue. They attacked each other at conferences and sent insulting emails.

The upheaval caused by the academic sub-field entering into the debate on the new direction of preschool education can be analysed using the second and third dimensions of field theory - by describing the symbolic order in the field, which is formed through the field's discourse, in the shape of statements, arguments, attempts to control definitions and so on, and by establishing who the main individual and collective actors in the field are.

The representatives of the academic sub-field attempted to influence the specific field and to supply it with new knowledge obtained from comparative experiences and research. Up until then the field's identity had not centred around academic knowledge but had been traditionalist and reproductive in nature, founded on positive collegial emotions. The sub-fields began to collide almost immediately after the largely academic team became involved in the creation of Slovakia's new preschool national curriculum in 2012. Arguably it was at this point that the field of preschool education in Slovakia started undergoing reconstruction. 
In this study the materials used to reveal the topology of this specific field and its sub-fields are the outputs of the consultations on the proposed new national curriculum, which was largely overseen by the academic sub-field. The consultation period, a process of political negotiation, presents an ideal opportunity to describe the ideational spectrum within the specific field of preschool education, and it is also provides a space in which actors with ambitions of power and wishing to maintain (or gain) control over the definitions can promote themselves. At the same it is an ideal setting for analysing the strategies the individual actors choose to exert influence over the power relations within the field.

As noted above the consultation, or power game, lasted for almost four years, during which the various sub-fields engaged in emotionally-laden battles against one another. Hundreds of pages of materials were gathered, many simply at the instigation of teachers or school heads. In our analysis, however, we focused on those illustrating collective or institutional attempts to influence the preschool specific field. Three sub-fields can be identified.

The first is the political sub-field of the preschool specific field. It includes representatives of organisations controlled by the ministry who were asked for their opinions on the proposed new national curriculum. Opinions were provided by the State Education Inspectorate (ŠŠI), Centre of Teaching Methods (MPC), National Institute of National Institution for Certified Education Measurements (NÚCEM), Research Institute for Child Psychology and Pathopsychology (VÚDPaP) and the education ministry's Regional Education Section (SRŠ). The second is the civic-professional sub-field containing professional associations, the Society for Preschool Education (SPV), OMEP and the Slovak Chamber of Teachers (SKU), who all commented on the new curriculum. The third is the academic sub-field, as some Slovak higher education faculties engaged in the consultation process.

\section{Discourse Struggle and Partnerships}

The academic sub-field was least successful in influencing the power struggle through its opinions. Its discourse contained no persuasive or emotional language. The language was that typically used in addressing the substantive aspects of the proposed measures or in discussions on the conceptual relevance of the different approaches, the area of education and so on. The political and civic-professional sub-fields operated on a different basis, quite clearly having ambitions of power and attempting to maintain control over definitions of the field and its symbolic order. 


\section{Admissibility of the jargon}

Those belonging to the civic-professional sub-field refused to admit new discursive unities into the field. They insisted on the original identification they had constituted themselves around - as positive collegial relations. This conflicted with the academic sub-field being constituted. The SPV position stated:

"The language used to formulate the performance standards in this area for pre-primary education is not familiar to everyone in the nursery school teaching profession"

In their opinion they provided specific examples of unclear terminology such as "communication conventions", or "explicit meaning of the text" and "implicit meaning of the text". For instance the OMEP rejected to the terms "categorisation", "scientific communication", "research effort" and "the formation of premises" arguing that they present difficulties for preschoolers. However, they did admit that the sub-field is established around other identifications than just specialist ones. Their rejection of the standard specialist terminology for that discipline (and education sphere) can be seen as a resistance strategy invoked in confrontations with the new sub-field.

Fears were also being expressed over the increasing power of the academic sub-field in the preschool field. The OMEP, for instance, by calculating the total number of standards in the curriculum, criticised the attempt to define educational content in a different way. During the consultation process OMEP representatives even created a special category of "hidden performance standards". This construct plays on the suspicion that there was a hidden agenda to manoeuvre the other sub-field into a position of distrust.

\section{Silencing authorship}

One interesting strategy relates to the position of the political sub-field. The SRŠ opinion states that:

"The names of those involved in drafting the national curriculum should not be published in it because it is a curriculum document and hence is not subject to the law on copyright and rights related to copyright"

This statement is interesting for a number of reasons. First it demonstrates the rationality of the political sub-field which is guided by its de- 
clared relationship with the formal legislation. One can infer that the part ruling out the publication of personal names was emboldened to make the warning categorical and emphatic. The demand, which is a rational one in the political sub-field does, however, contradict the field's previous history, when state officials were involved in drafting the national curriculum. The previous curriculum, produced under almost identical legislation, published the names of the authors. This may suggest that the comment (emitting not by chance from the political sub-field inhabited by a co-author of the previous curriculum) could be seen as a deliberate attempt to anonymise new players in the preschool education field. This would then make it a power-oriented communication strategy, where the aim is to maintain or reverse the power relations within the field to prevent new players gaining public legitimacy.

\section{Fighting the new}

In the opinions emanating from the political sub-field we find discursive unities that depict an atmosphere of total resistance. Certain new elements in the curriculum are identified as "alien" or "problem-inducing" (SRŠ). This creates an atmosphere which, were the new curriculum to be implemented under it, could lead to catastrophic consequences for preschool education.

In this sub-field strongly emotional discursive unities such as "children" or "childhood" began to be used for this purpose. This is a deliberate discursive strategy aimed at achieving homology with the civic-professional subfield and at interacting with its dominant emotional setting. According to the SRŠ the curriculum "in no way reflects childhood, children or play", and

"M. T. Brunšviková - the founder of the first childcare centre in Slovakia called for children in early years schools to play more..."

This was backed up by the statement:

"one cannot expect a preschool child to be capable of independent argument and discussion"

In this way an image was constructed of over-burdened children losing out on childhood and play as the dominant activities at preschool age.

In the political sub-field the VÚDPaP expressed a similar opinion:

"Despite the materials mentioning 'play' in the mediation of content, their 
complexity and the demand for management instead presage methods based on drills and dictations"

Again there is recourse to emotive language ("drill") which elicits negative emotions.

\section{Strategy of cohesion}

Above we stated that the political and civic-professional sub-fields were formed as homologous fields with porous boundaries and overlapping membership. Confronted with the new academic sub-field, the two fields opted for an attack strategy based on coordination between the two sub-fields. This can be seen in the consultation process. During it the two sub-fields consulted one another on their positions, with the political sub-field being the dominant player. It directly conveyed its opinion to the civic-professional sub-field and, owing to the membership overlap, the civic-professional subfield directly incorporated this into its own opinion.

This can be called a "copy and paste" strategy. In the opinions of the OMEP and SPV many passages were clearly taken directly and word-forword from passages in the SRŠ. This confirms our earlier statement that the civic-professional field was not traditionally an autonomous field and so power relations within it tended towards the heteronomy of the field. The fact that the SRŠ opinion appeared word-for-word in the comments produced by other actors in the political sub-field (ك̌S̆I, MPC) is natural given this situation.

\section{New players}

When characterising the specific field of preschool education we stated that the upheaval that led to the reconstitution/modification of the field also led to the appearance of other new actors. The greatest upheaval was felt in the sub-field that is by nature most open to the public space - the civicprofessional sub-field. During the consultation period it was represented by the Slovak Chamber of Teachers (SKU), whose preschool section was formed amidst the upheaval surrounding the national curriculum. Another new player to take part in the consultation process was the Slovak Association of Private Schools and Education Facilities (ASŠ).

Unsurprisingly, the two players produced opinions on the proposed national curriculum that diametrically opposed those of the traditional play- 
ers. Both assessed the innovative and relatively new components of the curriculum positively. The two opinions differed markedly in terms of discourse compared to those produced by the actors traditionally dominant in the field of preschool education. They did not close themselves off from the academic sub-field nor from the discourse. Their opinion addressed the conceptual aspects of the curriculum. They did not use categorical or emotional language. From the way the comments are constructed it is clear that this was an autonomous assessment of the proposed document and that strategic partnerships and ties were not sought out. There was no heterogeneous homology with the political sub-field evident in the case of these civic-professional players.

\section{New Beginning}

The upheaval associated with the redistribution of power amongst the preschool education sub-fields during this watershed moment formally ended with the education minister signing the new curriculum into force. By this time the power relations had been re-configured and the players were beginning to adapt their professional behaviour to the new power relations.

It has been demonstrated that the power struggle that played out on the declarative level as a battle over the quality of the education programme and in the name of the children was in fact merely the volatile and emotionallyladen redistribution of the fields of power. Once that had run its course the actors adopted moderate positions and began to engage with one another to ensure the curricular and conceptual changes in nursery schools were effectively implemented. The political actors returned to their work, producing for instance teaching support materials for nursery schools in accordance with the new curriculum and began building new pragmatic relationships with the publishing and civic-professional sub-fields. The outcome of the power-oriented upheaval was the diversification of the mass civic-professional field, which was redistributed into different groups with more clearly declared special interests and emancipatory links to the political field.

This process has probably permanently isolated the preschool field and its actors from the traditional homologous set up of fixed hierarchies. The whole painful and enduring process of the power conflicts between the various subfields has unambiguously led to the democratisation of the preschool field, the clarification of new positions of power and has encouraged the actors to engage in participative strategies of mutual communication. This is a very 
useful and necessary development in the national education field, particularly at a time when it is facing powerful pressures from the global education field in pursuit of its new interests and exerting its strategic pressure.

\section{Data sources}

Posudok - Štátny vzdelávaci program pre materské školy [Opinion - State Education Programme for Nursery Schools]. Bratislava: Výskumný ústav detskej psychológie a patopsychológie (Eva Farkašová)

Pripomienky $k$ návrhu Štátneho vzdelávacieho programu pre materské školy [Comments on the proposed State Education Programme for Nursery Schools]. Bratislava: Spoločnost' pre predškolskú výchovu (Jana Bolebruchová)

Pripomienky $k$ ŠVP pre ISCED O [Comments on the SED for ISCED O]. Bratislava: Štátna školská inšpekcia.

Pripomienky - ISCED O [Comments - ISCED 0]. Bratislava: Metodickopedagogické centrum.

Pripomienky $k$ návrhu Štátneho vzdelávacieho programu pre materské školy - máj 2014 [Comments on the proposed State Education Programme for Nursery Schools - May 2014]. Bratislava: Asociácia súkromných škôl a školských zariadení Slovenska (Beáta Nemcová).

Žiadost’o zapracovanie pripomienok do pripravovaného ŠVP pre MS̆ resp. do jeho sprievodných materiálov (do metodickej príručky) [Request for comments on the draft SEP for NS to be incorporated into the accompanying materials (the handbook)]. Bratislava: Slovenská komora učitelov (Eva Kurincová)

Pripomienky $k$ návrhu Štátneho vzdelávacieho programu pre materské školy, verzii predloženej na schválenie na Ministerstvo školstva, vedy, výskumu a športu Slovenskej republiky 17.4.2014 [Comments on the proposed 2014 State Education Programme for Nursery Schools, version submitted for approval to the Slovak Ministry of Education, Science, Research and Sport]. Bratislava: Sekcia regionálneho školstva MŠVVaŠ SR (Viera Hajdúková)

Pripomienky $k$ návrhu Štátneho vzdelávacieho programu pre materské školy z roku 2014 [Comments on the proposed 2014 State Education Programme for Nursery Schools]. Bratislava: Národný ústav certifikovaných meraní vzdelávania (Ingrid Alföldyová)

Štátny vzdelávaci program pre materské školy (predprimárne vzdelávanie) - pripomienky [State Education Programme for Nursery Schools (pre-primary education)]. Prešov: SV OMEP (Monika Miňová) 


\section{References}

André, G., \& Hilgers, M. (2015). Collective agents in the school field: Positions, dispositions and position taking in educational and vocational guidance. In M. Hilgers, \& E. Mangez (Eds.), Bourdieu's Theory of Social Fields. Concepts and applications (pp. 121-140). New York: Routledge.

Bourdieu, P. (1985). The social space and the genesis of groups. Theory and Society, 14 (6), 723-744.

Bourdieu, P. (1993). The field of cultural production. New York: Columbia University Press.

Buchholz, L. (2016). What is a global field? Theorizing fields beyond the nationstate. Sociological Review, 64 (2), 31-60.

Draxler, J. (2017). Školám škodí najmä chaos [Schools harmed by chaos]. Pravda, Retrieved April 18, 2017, from Pravda website: https://nazory.pravda.sk/analyzy-apostrehy/clanok/426748-skolam-skodi-najma-chaos /

Ferrare, J. J., \& Apple, M. W. (2015). Field theory and educational practice: Bourdieu and the pedagogic qualities of local field positions in educational contexts. Cambridge Journal of Education, 45 (1), 43-59.

Field, J. (2006). Lifelong learning and the new educational order. Stoke on Trent:

Trentham Books.

Grenfell, M. (2009) Applying Bourdieu's field theory: The case of social capital and education. Education, Knowledge and Economy, 3 (1), 17-34.

Grenfell, M., \& James, D. (2004). Change in the field - changing the field: Bourdieu and the methodological practice of educational research. British Journal of Sociology Education, 25 (4), 507-523.

Hilgers, M., \& Mangez, E. (2015). Introduction to Pierre Bourdieu's theory of social fields. In M. Hilgers, \& E. Mangez (Eds.), Bourdieu's theory of social fields. Concepts and applications (pp. 1-36). New York: Routledge.

Lima, R. C. P., \& Campos P. H. F. (2015). Field and group: A conceptual approximation between Pierre Bourdieu and the social representation theory of Moscovici. Educação e Pesquisa, 41 (1), 63-77.

Mengez, E., \& Hilgers, M. (2012). The field of knowledge and the policy field in education: PISA and the production of knowledge for policy. European Educational Research Journal, 11 (2), 189-205.

Naidoo, R. (2004). Fields and institutional strategy: Bourdieu on the relationship between higher education, inequality and society. British Journal of Sociology of Education, 25 (4), 457-471.

Rawolle, S., \& Lingard, B. (2008). The sociology of Pierre Bourdieu and researching education policy. Journal of Education Policy, 23 (6), 729-741.

Rubenson, K. (2008). OECD education policies and world hegemony. In R. Mahon, $\&$ S. McBride (Eds.), The OECD and transnational governance. (pp. 242-259). Vancouver: UBC Press.

Schmaus, D., \& Wimmer, R. (2013). Government policy and postsecondary education in Alberta: A 'Field Theory' analysis. Alberta Journal of Educational Research, 59 (1), 92-107. 
Tesar, M., Pupala, B. Kascak, O., \& Arndt, S. (2017). Teachers' voice, power and agency: (Un)professionalisation of the early years workforce. Early Years, 37 (2), 189201.

\section{Authors:}

Ondrej Kaščák, Assoc. Prof.

Trnava University

Department of School Pedagogy

Priemyselna 4

91843 Trnava

Slovakia

Slovak Academy of Sciences

Centre for Research in Education

Dubravska cesta 9

84104 Bratislava

Slovakia

E-mail: okascak@truni.sk

Branislav Pupala, Prof.

Trnava University

Department of School Pedagogy

Priemyselna 4

91843 Trnava

Slovakia

Slovak Academy of Sciences

Centre for Research in Education

Dubravska cesta 9

84104 Bratislava

Slovakia

E-mail:bpupala@gmail.com 